\title{
The Exploring of Marxism Regarding The Poverty Sustainability in Kampung Nelayan Seberang, Belawan, Indonesia
}

\author{
Bakhrul Khair Amal \\ Faculty of Social Science, State University of Medan (Unimed), Medan, Indonesia \\ b4khrul.4m41@gmail.com
}

\begin{abstract}
The phenomenon of poverty and the trap of poverty is a social reality that cannot be understood without exploring the phenomenon itself. The focus of this dissertation study is to look at the phenomenon of poverty that occurred in Seberang Village with the subject of research is fishermen's family. The phenomenon of poverty that is reflected in the poverty trap that ensnares the society of opposite the fishing village deserves to be explored in depth. The falsity of class consciousness comes from the class position in the economic structure of society. In other words, the people of Seberang Fisherman's Village experienced a form of false consciousness, namely the form of "resignation" to poverty that occurred. The effort they did to get out of the poverty trap is still an effort to utilize the aid with additional income sufficient for mere subsistence.
\end{abstract}

Keywords: poverty; humanism; society; phenomenon

\section{INTRODUCTION}

Kampung Seberang was chosen as the focal point of the study was not without reason. This region is facing directly with the growing industrial development, but this region has not been able to get out of the poverty trap and remain a slum in the city of Medan. Opposite the fishing village is a border area between Medan City and Deli Serdang Regency which in plain view indicates an overlap of interest in it. It is increasingly interesting when viewing Pelindo as a state-owned institution also turned out to have a big share of the presence of Opposite the fishing 
village. Marxian perspective use in macro and Chambers poverty trap idea in studying social construction happened as part of adaptation process of Opposite the fishing village community become feasible. at least there are three benefits that are expected to be obtained through this research, namely (1) obtaining a complete picture of the existence of elements of material deficiency, physical weakness, isolation, vulnerability, and helplessness as a component of poverty trap formed in the life of poor fishermen families in Medan. While other benefits are (2) exploiting Marxist thought related to the formation of social constructs related to the poverty trap that exists and the various forms of decisions that arise. This is useful in the government's efforts as a party deemed responsible for eradicating poverty through various development programs. The results of this study become materials to build a strategy of development implementation related to poverty alleviation, especially in urban fishing community. In simple terms, the results of this study are expected to be useful as a starting point in understanding poverty in the city of Medan and as an alternative to handle the problem of poverty in the city of Medan.

\section{REVIEW OF LITERATURE}

\subsection{Phenomenology}

According to the notion of phenomenology, science is not values free, free of any value, but values bound, has a relationship with value. The basic axioms of phenomenology are: (a) the reality exists in man, whether as an individual or a group, always multiple or multiple, and complexly arranged, so that it can only be examined holistically and indivisibly; (b) the relationship between the researcher and the subject of inquiry is difficult to separate; (c) leads more to cases, rather than generalizing the results of research; (d) it is difficult to distinguish between cause and effect, because the situation takes place simultaneously; (e) inquiry bound values, not values free. There are three main things that become the main concern of the phenomenology of individual awareness, activity, and behavior of individuals and daily life. In the context of 'consciousness', phenomenology is concerned with the way individuals or groups 
perceive, receive, understand, experience, respond, feel emotionally and attach to a particular subject. In terms of 'activity and behavior', phenomenology is interested in perceptions and conceptions about the world around which people can interact with each other. In this case, the phenomenological approach is actor centered or actor-centered, focusing on individual consciousness and this mode of consciousness directing and enabling action and interaction that are central components of social life. Meanwhile, 'everyday life' relates to the context in which individuals are located. The essence of phenomenology is the way this context is created through actions and interactions, and on the contrary this way of context also allows for action and interaction. The main insight of phenomenology is that "the understanding and explanation of a reality must be borne out of the phenomenon of reality itself" (Aminuddin 1990: 108). In its development, phenomenology exists in several ways, including: (a) Eidetic phenomenology in linguistics; (b) Ingenary phenomenology in literature; meaning pure understanding is determined by the determination of major phenomena, marking and sorting, filtering to determine existence, (reflection), (c) transcendental phenomenology, and (d) existential phenomenology. In general, only two phenomenological outlines are transcendental phenomenology (Husserl) and social phenomenology (Schutz).

\subsection{Phenomenology of Edmund Husserl}

For transcendental phenomenology, the existence of reality as an "object" is strictly emphasized. Active awareness in capturing and reconstructing awareness of a symptom is important. For the exclusionary phenomenology, the determination of cultural phenomena depends solely on the individual. Individual reflection becomes the "teacher" for the individual himself in order to discover the truth.In cultural studies, the development of the phenomenological approach is not directly influenced by the philosophy of phenomenology, but by developments in defining the concept of culture. In this case, the phenomenologist Edmun Husserl (in Muhadjir, 1998: 12-13) states that the object of science is not limited to the empirical (sensual), but includes a phenomenon that consists not of the perception, thought, a holistic approach, putting the object of research in a double construct, seeing its object in a natural 
context, rather than partial. Hence in phenomenology it is more to use logical thinking rather than just causal linear.

\subsection{Social Phenomenology of Schutz}

Schutz is one of the pioneers of the approach of social phenomenology as an analytical tool in capturing all the symptoms that occur in this world. In addition Schutz develops a more systematic, comprehensive, and practical approach to social phenomenology as a useful approach for capturing various phenomena in the social world. In other words, Schutz's thinking is a conceptual bridge between the phenomenological predictions of his predecessor whose nuances are social philosophy and psychology with social science directly related to humans on a collective level, society. Alfred Schutz's position of thought which is in the midst of pure phenomenology with social science thought led to the fruit of his thinking containing the concepts of both sides. The first party, pure phenomenology that contains the concept of social philosophical thought nuances of metaphysical and transcendental thinking on the one hand. On the other hand, social science thought is closely related to the various forms of interaction within society that are dispersed as symptoms in the social world. The symptoms in the social world are nothing but the object of the formal study (focus of interest) of the phenomenology of sociology. Schutz's thought becomes the basic reference of phenomenological research as an interesting study, but Schutz's thinking is actually no different from his predecessors. Schutz sees phenomenology as a social act on experience, meaning and consciousness. Man constructs meaning beyond the mainstream of his experience through the process of "typification". The interpretation of "tipping" in the context of phenomenology in Indonesia is interpreted as superficial as a grouping of human experience. In principle, "tipping" is a management, production of managed meanings, organized on the basis of relationships with information management or other experiences received by humans in the past. In the language of Schutz phenomenology called the "stock of knowledge", the process of the collection of experiences then affects the constructed meaning in thought patterns, movements, attitudes, behaviors and can be applied, implemented in reality in reality. The foundation of the ontology of Schutz's social phenomenology is Weber's concepts of value relevance, comprehension (verstehen) and the 
concept of ideal type. The concept of assimilation or the process of uniting the actual meaning is duality or ambiguity. For Schutz the meaning can be interpreted from various perspectives of human beings as social beings, meaning is born based on a subjective experience, constructed in man as an independent individual.

\subsection{Robert Chambers, About the Pitfalls Trap}

The conditions illustrated by many studies of the fishing communities in Indonesia as partly described above generally indicate the need for serious attention in tackling the poverty suffered by this community. This seriousness is necessary given the character of fishing communities and all related to their lives is different from other communities. Rambe (2002) implicitly stated in his writings that work as a fisherman is a very open and unlimited choice. In other words he says that work as a fisherman is a choice of "junk". The term "junk" happens because the process of recruitment into fishermen in coastal communities of Indonesia is not through the standard stage. This work is so easily accessible to those who can no longer be absorbed by other sectors. This is why this work can be conceived as an option for the wasted. With such conditions, the way of life and the character of those who work as fishermen become "unique". In harmony with the dimensions of work as fishermen are so open, systems and mechanisms of resource management exist in coastal communities which in many studies also closely related to the degree of welfare of fishermen also experienced the same thing. Borrowing economic terms, the resources that became the center of fishermen's life dependence are common property so that the emergence of tragedies on common property is very likely to happen. The concept of a common tragedy is a concept initiated by Garret Hardin in 1986. In his view, Hardin sees that all resources that are easily claimed to belong together will be potentially undermined by excessive exploitation because everyone has access to do so on the basis of that everyone is free to manage the shared resources (Hardin, 1986). Given that the life of fishermen is so distinctive, understanding their way of life is also becoming very important and widely practiced. Publication of Regulation (1985) about fishermen in Sinjai, Sulawesi reveals that fishermen's life there is heavily influenced by the pattern of relationship between fishermen who are not 
sufficient with fishermen who have capital and traders. The life of these two categories of fishermen is built on the principle of patrons and clients dominated by exploitative relationships. The same phenomenon is also seen by Kusnadi in many of his writings. A paper Kusnadi reveals that the life of fishermen occur with a very dynamic and season or weather is a dominant factor that affects the life of fishermen. He further explained that to anticipate fluctuations in income, fishermen build a life strategy by involving all household elements. One common adaptation strategy is the mobilization of the roles of women (wives) and their children to earn a living. The involvement of women in earning a living for families in coastal areas or fishing villages is inseparable from the division of labor by sex that applies to local communities (Kusnadi, 2000).

In addition to maximizing the potential of existing resources, fishermen strategies in maintaining their lives are also influenced by policy. The research conducted by the Coastal Community Empowerment team of PSKP Jember (2007) shows that policies that encourage the emergence of a pattern of natural resource management in coastal areas with principles of justice will ensure the welfare of fishing communities. Therefore, the results of the team review formulate the commitment and consistency of the government in encouraging the emergence of pattern of management of natural resources of coastal and sea just need to be done. Understanding that the phenomenon of poverty in the fishing community is not a simple but complex phenomenon, the various attempts to overcome it should also no longer be partial but integrated, integrated and sustainable. The phenomenon of the emergence of a government program of partial and sectarian government empowerment has been the concern of many circles. On the condition of the struggle effort to examine the poor condition always appears and seems sustainable, so many experts are trying to analyze it, including Robert Chambers (1983). His long-term struggle in the poverty alleviation program spawned the notion that poverty is a symptom that does not happen by itself but relates to a set of elements that individually or in groups together produce something called a poverty trap. In this research, the poverty-forming trap elements become tools used to create a social construction based on the facts. In accordance with the definition of Robert Chambers (1983) that the core of the problem of poverty lies in the deprivation trap or "poverty trap" which 
contains five elements, namely material deficiency, physical weakness, isolation or isolation, vulnerability, and helplessness.

\section{METHOD OF THE RESEARCH}

The phenomenon of poverty and the trap of poverty is a social reality that cannot be understood without exploring the phenomenon itself. The focus of this dissertation study is to look at the phenomenon of poverty that occurred in Seberang Village with the subject of research is fishermen's family. The phenomenon of poverty that is reflected in the poverty trap that ensnares the society of Opposite the fishing village deserves to be explored in depth. Thus phenomenology became an effective approach to uncover the phenomenon of poverty in this study. Supported by the opinion of Siahaan (2001), based on a phenomenological perspective, poverty is a social reality experienced by a poor household, therefore their own household is more appropriate to describe it. Before discussing further, here are some proofs of the relevance of phenomenology in the social sciences; Schutz (1967)

a. As a methodological approach typical of the problems of sociology studies, namely human and interaction patterns of life.

b. Phenomenology as a source of real insight and knowledge of social issues and phenomena.

c. As the construct of descriptive material for social gait and modernity experience.

\section{DISCUSSION}

Marx's focus is on developing his theory at the level of social structure, not at the level of socio-cultural reality, or in other words: Marx does not focus on studying the way individuals adapt to the physical environment but to individual positions influenced by socio-cultural interactions based on matter. The realization of Marx as "real democracy" according to his analysis, brings with it the prevention of alienation between individuals and society, this is done by fusing the dichotomy between the selfish interests of individuals in civil society and the social 
nature of political life. This fusion can only be achieved by making concrete changes in such a way in the pattern of state and society relations, so that now only ideal ideals (universal political participation) become the real thing. Marxism believes that a successful transition to communism, which clearly means a society without a state will require a repression of the capitalists who are allowed to rebuild its power and the necessity of the existence of the state in a form controlled by its workers. Marx (in Maghnis, 2001) defines the conception of the state as a manifestation of the irreconcilable antagonism of social classes within society. In the analysis of historical materialism that ultimately led to a conception of the state, Marx described that the history of all societies that exist today is the history of the class struggle. The clashing of the class of the past when the free and the slaves contradicted each other, the lords of the nobility and the servants, the craftsmen and the assistants. In short, the oppressor and the oppressed. For Marx in writing the history of the world community, to the emergence of the state at each phase, must focus on the people who experience the development of history. This position of Marx assumes the state as a product of society in which there are social classes, which in its development always have a sharp contradiction, between the sucking class and the sucked class (owners and those without the means of production). In the book by Franz Magnis-Suseno (2001); Karl Marx's thought of Utopian Socialism to the Revisionism Dispute, Marx says, determines the development of society rather than consciousness and not what society thinks of itself, but the real state of society. Marx departs from real and active human beings and from their real-life processes the development of reflexes and the ideological echoes of this life process are explained. This Marxian argument is derived from the core philosophy of dialectical materialism and historical materialism. The explanation of the marxism of sustainable poverty in Opposite the fishing village is seen from the sharp contradiction between the sucking and smoked classes. This view is clearly visible from the government policy that puts the existence of Seberang Village community is not important, making their existence is seen in the eye by some parties. The contradictions indicate an organized pattern of the state. Never mind expensive fuel prices, the capital of the sea also sometimes debt, plus the price of fish suppressed middlemen, the cost out 
the village was expensive. Ah, it's as bad as we can. But who wants to complain? Only God knows our suffering these peripheral people. (Interview October 25, 2015)

The organized pattern created by the state can only be understood in terms of the state with the class structure that makes it appear (Green, 2004: 137). In other words, the relationship of class structure to the existence of the state contributes to the contradictions of understanding of the Opposite the fishing village region as well as a region worthy of a powerless territory. Gramsci (2013) itself states as long as the state class exists, then the regular society will not exist. This is not only seen as a metaphor where the confusion of the state class and the organized society is typical for the lower middle class, which is happy to accept any regulation or regulation. The existence of Pelindo, Deli Serdang and Medan as the representation of the state will not make a regular society in Opposite the fishing village.

Figure 1. Thinking Framework of Marxism in the Village of Fishermen Seberang

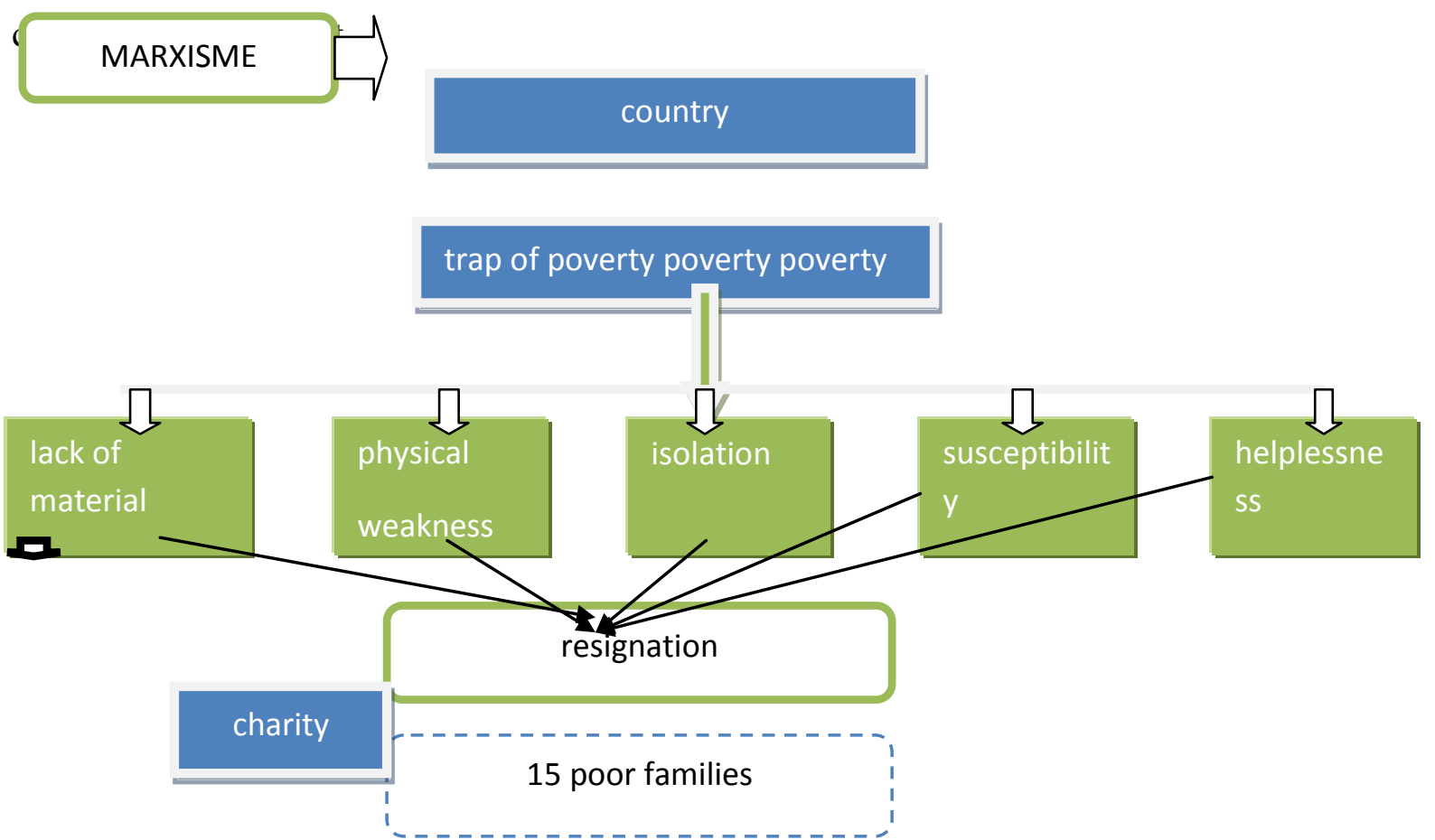

Lenin's view of the state which is a manifestation of the irreconcilable antagonism of social classes found in society becomes interesting when looking at the context of Seberang Fisherman's Village. Like a text that should not be far from its context, Lenin's view of the state 
and the consciousness of the class need to be understood as a view that is not always absolute. It is seen that the state gives people a chance to settle in the area, helping with the existing aid program but its condition does not lift them to a better standard of living. Consequently, subsistence activities for aid often occur. This condition does not cause the public to be aware of the position to which it ought to be, or even to fight for its own interests to be subdued by power beyond its power. The complexity of the problem is what causes the poverty in Seberang Fishermen Village. The view of Marxism is clearer when looking at the eyes of poverty traps that have been presented through the representation of five poor families Seberang Fisherman's Village. Countries in this context bind people to remain in poverty. This is very clear when the state only accommodates the poverty of the element of material shortage, while the other four elements of poverty trap are left alone. As a result the country only gives "fish" without giving a way to get the fish.

\section{CONCLUSION}

To digest poverty and development products in Seberang Fisherman's Village there is a match between the two. This results in a perpendicular relationship between the two products produced. The product of poverty, that is resignation, is basically reinforced by the assistance that it does not provide a form of solution. The impression of assistance originally accepted by the public is the main point. But the dilemma of the aid is not seen as important and tends to be ignored, such as the negative response and the opium process of the aid. The relation between poverty and development products is seen from the above chart. The dialectic of poverty and development that results in a form of resignation and assistance in accordance with Lukacs's Concept of false consciousness that states generally do not have a clear understanding of their class consciousness. For example, the people Seberang Fisherman's Village are not really aware of their real class, they are only aware that they are poor and are trying to get out in poverty by taking advantage of government assistance. The falsity of class consciousness comes from the 
class position in the economic structure of society. The effort they did to get out of the poverty trap is still an effort to utilize the aid with additional income sufficient for mere subsistence.

\section{REFERENCES}

Ade, Subarkah. 2012. Jurnal. Kapitalisme, Sosialisme dan Kemiskinan (Perspektif Materialisme Karl Marx dan Idealisme Max Weber).

Adian, Donny Gahral. 2005. Percik Pemikiran Kontemporer: Sebuah Pengantar Komprehensif. Yogyakarta: Jalasutra.

Agger, Ben. 2014. Teori Sosial Kritis (Kritik, Penerapan, dan Implikasinya). Bantul: Kreasi Wacana.

Alfian, Mely G.Tan dan Selo Soemardjan (e.ds.), 1980. Kemiskinan Struktural; Suatu Bunga Rampai. Malang: HIPIS.

Aminuddin. 1990. Metode Kualitatif dalam Penelitian Karya Sastra, dalam Aminuddin (ed.). Pengembangan Penelitian Kualitatif dalam Bidang Bahasa dan Sastra. Malang: Yayasan Asih, Asah, Asuh.

Grondin, Jean. 2010. Sejarah Hermenitik (dari Plato Hingga Gadamer). Yogyakarta: Ar Ruzz Media

Hadiwijono, Harun.1980. Sari Sejarah Filsafat Barat 2.Yogyakarta: Kanisius.

Harahap, R. Hamdani. 1992. Pengembangan Kapasitas Perencanaan Daerah dalam Pengelolaan Kawasan Pesisir Secara Terpadu di Pantai Tumur, Propinsi Sumatera Utara elayan dan Kemiskinan (studi Antropologis di Desa Paluh Sibaji. Disertasi S3. Program Studi Pengelolaan Sumberdaya Alam dan Lingkungan. Medan: Universitas Sumatera Utara

Harahap, R. Hamdani. 1992. Nelayan dan Kemiskinan (studi Antropologis di Desa Paluh Sibaji, Kecamatan Pantai Labu, Kabupaten Deli Serdang. Laporan Penelitian. Lembaga Penelitian USU-Medan.

Harry, Hikmat. 2001. Strategi Pemberdayaan Masyarakat. Bandung: Humaniora Utama Press (HUP). 
Hardin, Garret. 1968. The Tragedy of the Commons on Science Magazine edition 162. (13 December) p 1243 -1248. Washington.

Huaco. GA. 1986. Ideology and General Theory: The Case Of Soscial Functionalims. Comp Stud Hist, 28, -34 -54.

Jacky. Muhammad.2015. Sosiologi, Konsep, Teori dan Metode. Jakarta. Mitra Wacana Media.

Kartasamita, Ginandjar. 1995. Pidato Pengukuhan Jabatan Guru Besar dalam Ilmu Administrasi. Pemberdayaan Masyarakat: Sebuah Tinjauan Administrasi. Malang: Universitas Brawijaya.

Kling, Zainal. 1985. Strukturalisme dan Pengajian Melayu dalam Struktural satu Tinjauan Multidisiplin oleh Nik Safiah Karim (editor). Kuala Lumpur: Jabatan Pengajian Melayu Universitas Malaya.

Korten, David C. 1993. Menuju Abad 21: Tindakan Sukarela dan Agenda Global. Jakarta: Yayasan Obor Indonesia dan Pustaka Sinar Harapan.

Muhadjir, Noeng. 2000. Metodologi Penelitian Kualitatif. Edisi IV. Yogyakarta: Rake Sarasin. Moeryadi, Denny. 2009. Pemikiran Fenomenologi Menurut Edmund Husserl (bagian I dan II) pada http://jurnalstudi.blogspot.com/2009/03/pemikiran-fenomenologi-menurutedmund.html diakses pada 12 Mei 20013.

Muhadjir, N. 1998. Metodologi Penelitian Kualitatif. Edisi Kedelapan. Yogyakarta: PT. Bayu Indra Grafika.

Nasrullah. Adon. 2015. Sosiologi Perkotaan, memaham masyarakat kota dan problematikanya. Bandung. Penerbit Pustaka Setia.

Patria, Nezar dan Andi Arief. 2009."Antonio Gramsci, Negara dan Hegemoni”.'Yogyakarta: Pustaka Pelajar.

Poloma, Margaret M. 2004. Sosiologi Kontemporer. Jakarta: Raja Grafindo.

Rambe, Saruhum. 2002. Menuju Nelayan Sejahtera dalam Buletin JALA Edisi XVIII Mei-Juni. Medan: JALA. 
Resusun, Demianus. 1985. Dayung Basah Periuk Berisi. Studi tentang Beberapa Aspek Sosial Ekonomi Nelayan Bagang di Pulau Sembilan dalam Mukhlis dan Kathryn Robinson. Masyarakat Pantai. Ujung Pandang: Lembaga Penelitian Universitas Hasanuddin.

Ritzer. George dan Douglas J. Goodman. “Teori Sosiologi, dari teori sosiologi

klasik sampai perkembangan mutakhir teori sosial postmodern". Bantul: Kreasi Wacana.

Salim, Agus, 2001. Teori dan Paradigma Penelitian Sosial, Yogyakarta: Tiara Wacana.

Samandawai, Sofyan. 2001. Mikung: Bertahan dalam Himpitan, Kajian Masyarakat Marjinal di Tasikmalaya. Bandung: Yayasan Akatiga.

Schutz, Alfred, 1967, The Phenomenology of The social World, German: Der Sinnhafie Aufbau Der Sozialen.

Smith, David Woodruff. 2007. Husserl. London: Routledge.

Soetrisno, Loekman. 1997. Kemiskinan, Perempuan dan Pemberdayaan.

Yogyakarta : Penerbit Kanisius.

Suparlan, D. P. 1984. “Kemiskinan di Perkotaan.”. Jakarta: Penerbit Sinar Harapan dan Yayasan Obor Indonesia.

Suryawan, I Ngurah. 2010." Genealogi Kekerasan Dan Pergolakan Subaltern: Bara di Bali Utara. Jakarta: Prenada Media Group.

Suyanto, Bagong dan Karnaji. 1995. Perangkap Kemiskinan. Problem \& Strategi Pengentasannya. Surabaya: Airlangga University Press

=========== 2005. Kemiskinan Dan Kesenjangan Sosial : Ketika Pembangunan Tak Berpihak Kepada Rakyat Miskin. Surabaya: Airlangga University Press.

Thao, Tran Duc. 1971. Phenomenology and Dialectical Materialism. Translated Daniel. J Herman and Donald V. Morano. Boston. D.Reidel Publishing Company.

Tim Pemberdayaan masyarakat Pesisir PSKP Jember. 2007. Strategi Hidup Nelayan. Yogyakarta: Diterbitkan atas kerjasama PSKP Jember dan LKiS:

Tjokrowinoto, Moeljarto. 1996. Pembangunan: Dilema dan Tantangan. Yogyakarta: Pustaka Pelajar. 
Turner, Jonathan. $\mathrm{H}$ dan Alexandra Maryanski. 1979. Functionalism. California: Benjamin/Cummings Publishing Co. Inc.

Yulianto Kadji. 2012. "Kemiskinan dan Konsep teoritisnya". Jurnal.

Zulkifli. 1989. "Pemborong dan Nelayan: Pola Hubungan Patron dan Klien pada Masyarakat Nelayan (Studi Kasus pada Masyarakat Bagan Deli Kecamatan Medan Belawan, Kotamadaya Medan)”. Tesis S2 tidak Diterbitkan. Jogjakarta: Fakultas Pascasa 